\title{
A LECITHINASE A IN DUODENAL CONTENTS OF MAN
}

\author{
By WILLIAM C. VOGEL and LESLIE ZIEVE \\ (From the Radivisotope Scrvice and Department of Medicine, Veterans Administration Hos- \\ pital, Unizersity of Minnesota, Minneapolis, Minn.)
}

(Submitted for publication March 7, 1960; accepted March 31, 1960)

Lecithinase A catalyzes the removal of a fatty acid from lecithin or the cephalins to yield lysolecithin or the lysocephalins which are particularly noted for their lytic effect on red blood cells (1). Hanahan (2) studied the action of the enzyme in extracts of pancreatin on lecithin in diethyl ether. This method was used by Hanahan, Rodbell and Turner (3) and improved by Long and Penny (4) in studies of the action of the enzyme in venom on natural and synthetic phosphoglycerides. Epstein and Shapiro (5) and Rimon and Shapiro (6) measured the enzyme from rat intestinal mucosa and ox pancreas in phosphate buffer.

Borgström's (7) report of the almost complete conversion of lecithin in bile to lysolecithin in the upper small intestine of man prompted us to undertake the measurement of the enzyme involved. A simplified assay was evolved using the fasting duodenal contents of man as the source of enzyme. The release of fatty acids from lecithin was measured titrimetrically. The concurrent decrease in lecithin and equivalent increase in lysolecithin were measured by quantitative chromatography using silicic acid impregnated paper $(8,9)$. Some factors which increase or decrease the sensitivity of the assay were also evaluated.

\section{EXPERIMENTAL METHODS}

Duodenal contents as a source of pancreatic secretion were obtained from 5 men by aspiration. Collections varied in bile content. Lyophilized cobra venom (Naja naja) was obtained from the Ross Allen Reptile Institute; it was used as a source of lecithinase A only once, as specifically indicated.

Pure lecithin, lysolecithin and sphingomyelin were prepared from egg yolk by the method of Lea, Rhodes and Stoll $(10,11)$. Purity of the eluates used was determined by paper chromatography (8). Moles of egg lecithin were calculated as (linoleylstearoyl)-glycerylphosphorylcholine. (Dipalmitoleyl)-glycerylphosphorylcholine and ( $\beta$-monostearoyl)-glycerylphosphorylcholine were provided through the kindness of Dr. D. J. Hanahan.
All evaporations were carried out with a rotary film vacuum evaporator at $40^{\circ} \mathrm{C}$ and approximately $18 \mathrm{~mm}$ $\mathrm{Hg}$. Lecithin substrates were prepared by evaporation of a methanol: chloroform solution (approximately $1: 1$, $\mathrm{vol} / \mathrm{vol}$ ) of lecithin, addition of a buffered solution of activators, and emulsification and partial solution of the mixture with a laboratory shaker.

The total release of fatty acids in the incubations was measured by the method of Dole (12). One ml aliquots were extracted immediately after addition of enzyme and at selected time intervals thereafter. A one-phase titration was obtained by preparing the indicator and alkali in absolute ethanol.

Lipid extracts for phospholipid chromatography were prepared by the addition of $1 \mathrm{ml}$ of the incubation mixture to approximately $18 \mathrm{ml}$ of ethanol: ether $(3: 1, \mathrm{vol} /$ vol), heating to boiling, and diluting with the ethanol: ether to $25 \mathrm{ml}$ at room temperature. After filtering through lipid-free filter paper, a $20 \mathrm{ml}$ aliquot was evaporated to dryness and the lipids dissolved in $3 \mathrm{ml}$ of isoamyl alcohol: benzene $(1: 1, \mathrm{vol} / \mathrm{vol}) ; 100 \mu \mathrm{l}$ was applied to the paper for each analysis unless otherwise indicated.

The identification of phospholipids on silicic acid impregnated filter paper was made essentially using the techniques of Marinetti, Stotz, Erbland and Kochen (8, 9). The solvent system diisobutyl ketone: acetic acid: water $(40: 30: 7, \mathrm{vol} / \mathrm{vol})$ was used in this study. Quantitative estimations of the individual phospholipids were made by phosphorus analyses following their elution from the paper. Phosphorus was determined by our modification of the method of Beveridge and Johnson (13) in which $1 \mu \mathrm{g}$ of phosphorus yields an absorbancy of 0.173 in $1 \mathrm{~cm}$ cells. Our recoveries were typically 85 to 95 per cent, using phospholipids applied individually or as mixtures at levels of 0.6 to $5.7 \mu \mathrm{g}$ of lipid phosphorus. Values reported were corrected for an average 90 per cent recovery, and expressed as amount present in the total incubation mixture.

Borate buffer, $0.05 \mathrm{M}$, was prepared by adding potassium hydroxide solution to $50.0 \mathrm{ml}$ of $0.2 \mathrm{M}$ boric acid until the desired $\mathrm{pH}$ at $200 \mathrm{ml}$ volume was reached. Solutions in this buffer were made prior to final $\mathrm{pH}$ adjustment.

Sodium deoxycholate was purified by the following procedure (14): $10 \mathrm{~g}$ was dissolved in $50 \mathrm{ml}$ of 95 per cent ethanol, filtered, concentrated to $20 \mathrm{ml}$, and added slowly to $150 \mathrm{ml}$ cold ethyl ether. The crystals were washed with ether and then dried, utilizing a vacuum evaporator as for lipid extracts, advancing the temperature to $98^{\circ} \mathrm{C}$ for 10 minutes. 
RESULTS

Enzymatic action of duodenal contents. The similarity of action of duodenal contents and cobra venom on the lecithin and phosphatidylethanolamine of an aqueous egg yolk emulsion is shown with silicic acid chromatograms in Figure 1. This means of following the enzymatic degraclation of phospholipids was then used to follow the conversion of pure lecithin to lysolecithin by duodenal ccntents. With egg lecithin or lecithin in blood se-

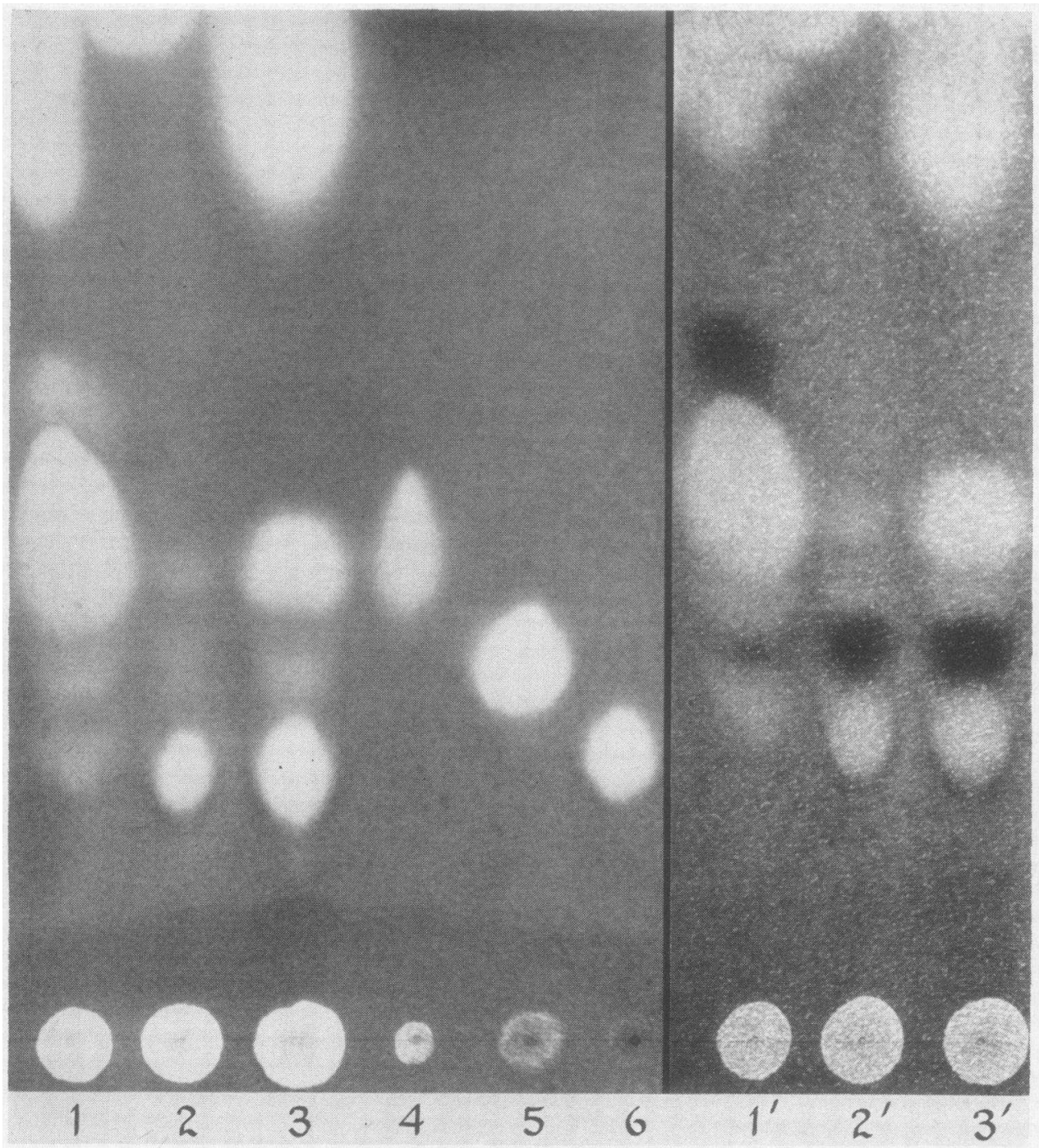

Fig. 1. The action of cobra venom and duOdenal contents on egg phospholipids. Three separate incubations for 2 hours at $38^{\circ} \mathrm{C}$ were made, using $5 \mathrm{ml}$ of one egg yolk emulsified in $100 \mathrm{ml}$ of water and adding : a) $1 \mathrm{ml}$ of water as a control, b) $2 \mathrm{mg}$ dried venom in $1 \mathrm{ml}$ water, c) $1 \mathrm{ml}$ of duodenal contents. After preparation of extracts, $50 \mu \mathrm{l}$ from incubations $a$ and $c$ were applied at origins 1 and 3 while $25 \mu \mathrm{l}$ from $b$ was applied at 2 . The amount of phospholipid contributed to 3 by duodenal drainage is negligible. Pure egg lecithin, sphingomyelin, and lysolecithin were applied at origins 4, 5, and 6, respectively. On the left the chromatogram was stained with rhodamine G. On the right the cephalin compounds (phosphatidylethanolamine and lysophosphatidylethanolamine) are shown by the additional application of a ninhydrin spray. Not indicated are an area above 2 midway between origin and lysolecithin showing a blue fluorescence when wet, and a slightly positive ninhydrin area at the lower edge of lysolecithin in $3^{\prime}$. Time exposure photographs taken under ultraviolet illumination (dry chromatogram, Eastman Panatomic-X film, Wratten filter no. 85, f.12, 5 sec. exposure). 


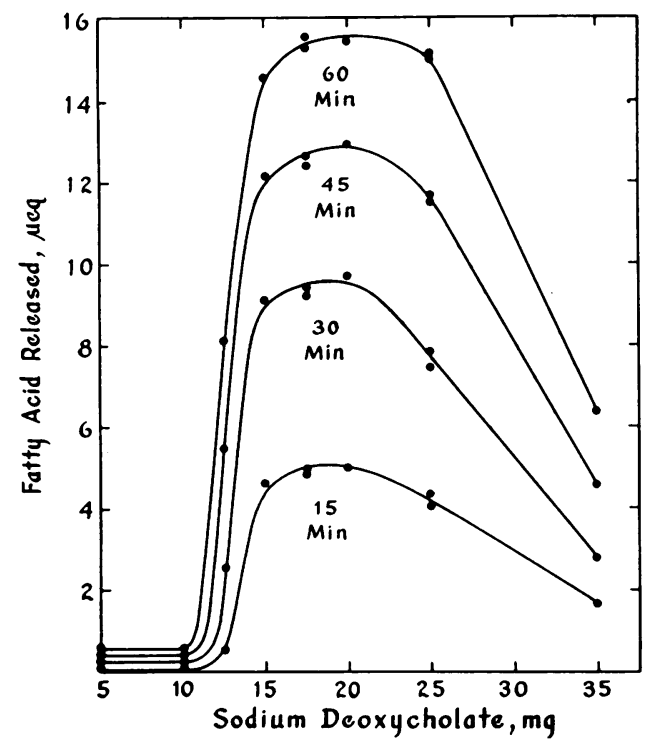

Fig. 2. THE EFFECT OF SODIUM DEOXYChOLATE ON Lecithinase A. Separate substrates contained $25 \mathrm{mg}$ (31.1 $\mu \mathrm{M}$ ) lecithin and varying amounts of sodium deoxycholate in $5 \mathrm{ml}$ borate buffer, $\mathrm{pH}$ 8.4. The enzyme source was diluted 1:16 with the same buffer. After equilibrating separately at $38^{\circ} \mathrm{C}, 1 \mathrm{ml}$ of enzyme was added to each substrate and incubated at $38^{\circ} \mathrm{C}$. Fatty acids released were measured at the time intervals shown. Duplicate reaction systems were as plotted.

rum the reaction with duodenal aspirate proceeded only to lysolecithin with the equivalents of fatty acid released equal to the molar decrease in lecithin and increase in lysolecithin as measured by phosphorus analyses. The simpler measure of fatty acids released could then be used in studies of the enzyme.

Selection of buffer. With 1:10 dilutions of the enzyme source in various buffers, 0.05 to 0.1 $\mathrm{M}$, over the $\mathrm{pH}$ range 6.0 to 8.1 , the greatest liberation of fatty acids occurred in a borate buffer at $\mathrm{pH}$ 7.4. The enzymatic activity was slightly less in Tris-(hydroxymethyl)-aminomethane buffer at

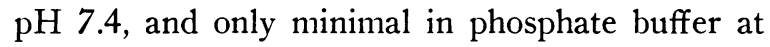
$\mathrm{pH} 7.0$, the most commonly used buffer in studies of this enzyme.

Effect of sodium deoxycholate. In borate buffer the activity of a 1:25 dilution of enzyme source was 7 per cent of the activity of a $1: 10$ dilution, instead of the expected 40 per cent. It was found that the addition of various bile salts to the system prevented the loss of activity with dilution of the enzyme and that, in appropriate concentra- tion, bile salts had a marked activating effect. Preliminary studies indicated that sodium deoxycholate was the most effective of the bile salts tested. The optimum $\mathrm{pH}$ was shifted to 8.4 as will be shown later. Figure 2 illustrates the effect of varying the amount of deoxycholate in the system used. Nonenzymatic reaction in controls was negligible. Twenty and $100 \mathrm{mg}$ amounts of two non-ionic detergents, a polyoxyethylene lauryl ether and a polyoxyethylated nonylphenol, had no activating effect.

Effect of amino acids. Of the amino acids studied, glycine was the most effective in increasing the action of lecithinase A. A marked increase in activity was seen at a $0.01 \mathrm{M}$ concentration, and a point of only slight additional increments in activity was reached at 0.05 to $0.15 \mathrm{M}$. We elected to use $0.1 \mathrm{M}$ glycine in $0.05 \mathrm{M}$ borate at $\mathrm{pH} 8.4$. Figure 3 compares its activating effect with that of other amino acids. It also shows that varying molarities of borate buffer by itself give identical results.

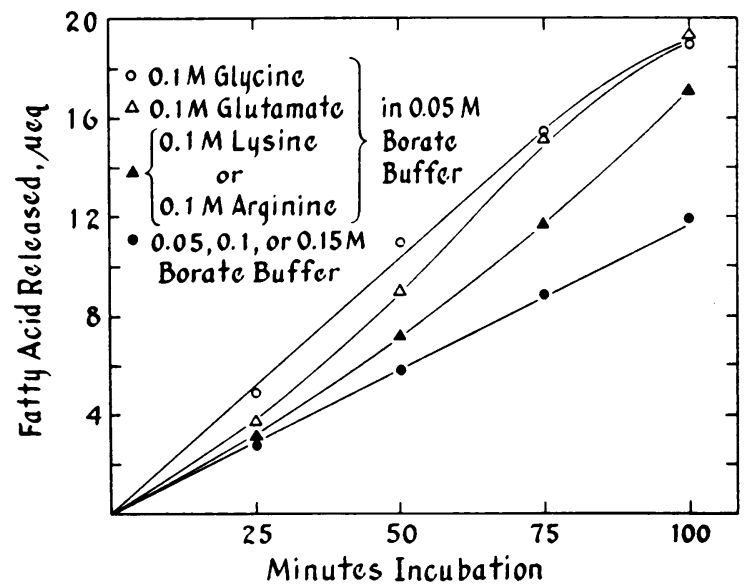

Fig. 3. Effect of amino acids on lecithinase A. Substrates contained $25 \mathrm{mg}(31.1 \mu \mathrm{M})$ lecithin and $20 \mathrm{mg}$ sodium deoxycholate dissolved in either $5 \mathrm{ml}$ of 0.05 , 0.10 , or $0.15 \mathrm{M}$ borate buffer, $\mathrm{pH} 8.4$, or $5 \mathrm{ml}$ of a $0.1 \mathrm{M}$ solution of glycine, monopotassium glutamate, lysine hydrochloride or arginine hydrochloride in $0.05 \mathrm{M}$ borate buffer, $\mathrm{pH}$ 8.4. After equilibrating separately at $38^{\circ} \mathrm{C}$, $1.0 \mathrm{ml}$ of enzyme source, diluted $1: 32$ with $0.05 \mathrm{M}$ borate buffer, $\mathrm{pH} 8.4$, was added to each substrate and incubated at $38^{\circ} \mathrm{C}$ for the time intervals shown. The results for the three different concentrations of borate buffer and for the lysine and arginine were each so nearly identical that a single curve was drawn through the means of the respective values at the four incubation times. 


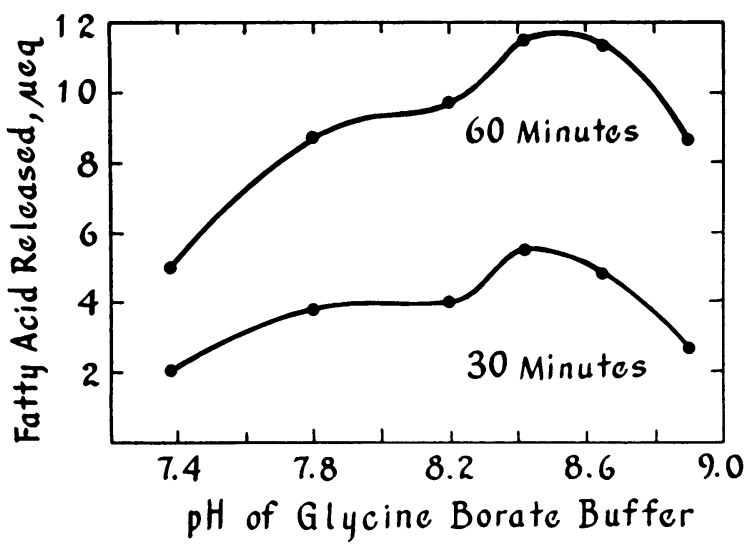

Fig. 4. The effect of $\mathrm{PH}$ ON THE ACtivity OF LeCITHINASE A. The reaction system contained $25 \mathrm{mg}$ (31.1 $\mu \mathrm{M}$ ) lecithin and $20 \mathrm{mg}$ sodium deoxycholate in $5 \mathrm{ml}$ of $0.1 \mathrm{M}$ glycine in $0.05 \mathrm{M}$ borate buffer at different $\mathrm{pH}$ 's, and $1 \mathrm{ml}$ of a $1: 32$ aqueous dilution of the enzyme source. Equilibration and incubation at $38^{\circ} \mathrm{C}$. No correction was made for the slight effect of deoxycholate on the $\mathrm{pH}$ of the system.

Optimum pH. Figure 4 shows that the optimum pH falls between 8.4 and 8.5. Subsequent studies were performed at a $\mathrm{pH}$ of 8.45 . Studies

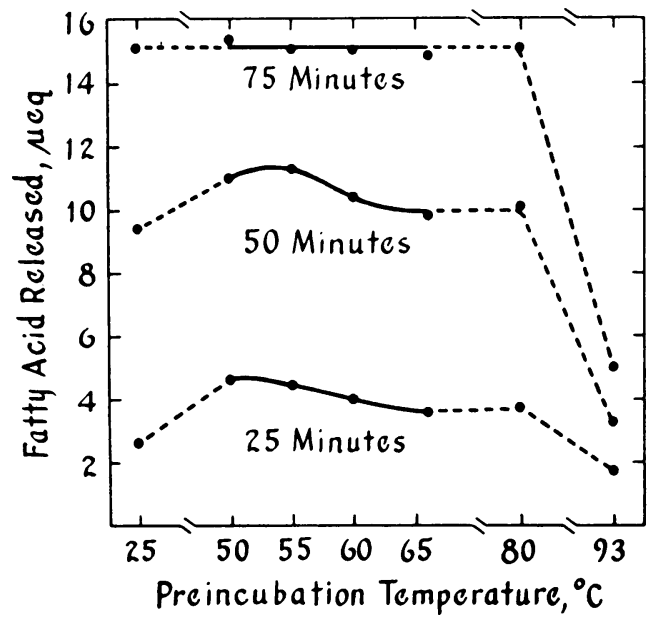

Fig. 5. Heat stability of lecithinase A. An aliquot of a 1:32 dilution of enzyme source in glycine borate buffer was held at room temperature as a control and other aliquots were pre-incubated for 30 minutes at temperatures ranging between $50^{\circ}$ and $93^{\circ} \mathrm{C}$. After equilibration at $38^{\circ} \mathrm{C}, 1 \mathrm{ml}$ portions of these aliquots were incubated at $38^{\circ} \mathrm{C}$ with a substrate containing 25 $\mathrm{mg}(31.1 \mu \mathrm{M})$ lecithin and $20 \mathrm{mg}$ sodium deoxycholate in $5 \mathrm{ml}$ glycine borate buffer. Fatty acids released at 25,50 and 75 minutes were measured. A control incubation with buffer in place of enzyme showed a change of $-0.08,-0.08$, and $+0.06 \mu \mathrm{Eq}$ fatty acids at 25,50 , and 75 minutes, respectively.

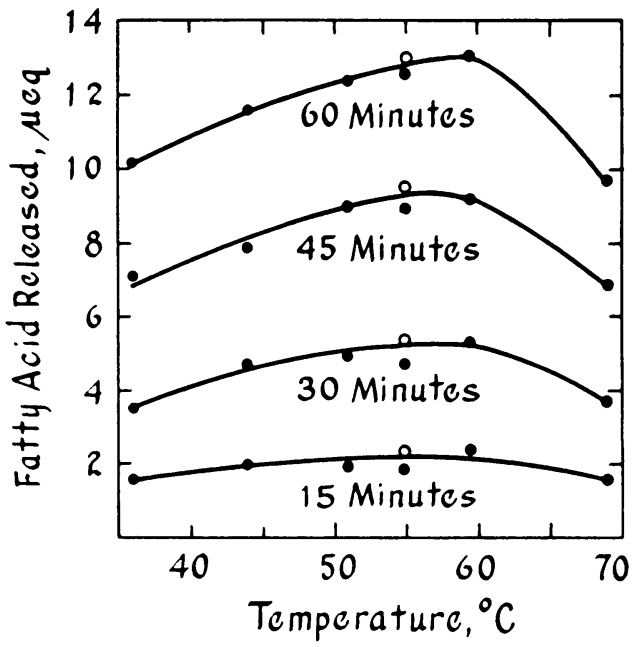

Fig. 6. Optimum incubation temperature. Pairs of tubes, one containing $1 \mathrm{ml}$ of enzyme source diluted $1: 32$ and the other $6 \mathrm{ml}$ of substrate, were pre-incubated 30 minutes at temperatures from $36^{\circ}$ to $69^{\circ} \mathrm{C}$. Then $5 \mathrm{ml}$ of the substrate was added to the enzyme tube and incubated at the pre-incubation temperature. The fatty acids released in $15,30,45$, and 60 minutes were measured. The effect of pre-incubation for 60 minutes at $55^{\circ}$ $\mathrm{C}$ is indicated by the open circles. A control of $1 \mathrm{ml}$ of buffer in place of enzyme at $55^{\circ} \mathrm{C}$ showed a release of $0.18,0.39,0.53$, and $0.48 \mu \mathrm{Eq}$ fatty acids, respectively, at the time intervals indicated.

reported in the literature have been carried out near $\mathrm{pH} 7.0$ (1-6).

Heat stability and incubation temperature. The marked heat stability of lecithinase A reported by others was also found in our assay system as shown in Figure 5. The enzyme was pre-incubated for 30 minutes at different temperatures and then incubated at $38^{\circ} \mathrm{C}$. The flattening of the curve at 75 minutes is a reflection of the slowing of the reaction rate when one-half the lecithin is hydrolyzed. The peak of activity, seen at $50^{\circ}$ to $60^{\circ} \mathrm{C}$ for the shorter incubation periods, is further clarified in Figure 6 which presents results of enzyme action with pre-incubation and incubation in the temperature range, $36^{\circ}$ to $69^{\circ} \mathrm{C}$. The enzyme and substrate in the experiment of Figure 6 were prepared as described in the following paragraph. Wakui and Kawachi (15) recently reported a very similar temperature curve for the enzyme in cobra venom, although they used a different assay system. By way of contrast, lipase is clestroyed at $55^{\circ} \mathrm{C}(16)$.

Optimal incubation system. In subsequent experiments, $0.1 \mathrm{M}$ glycine in $0.05 \mathrm{M}$ borate buffer 


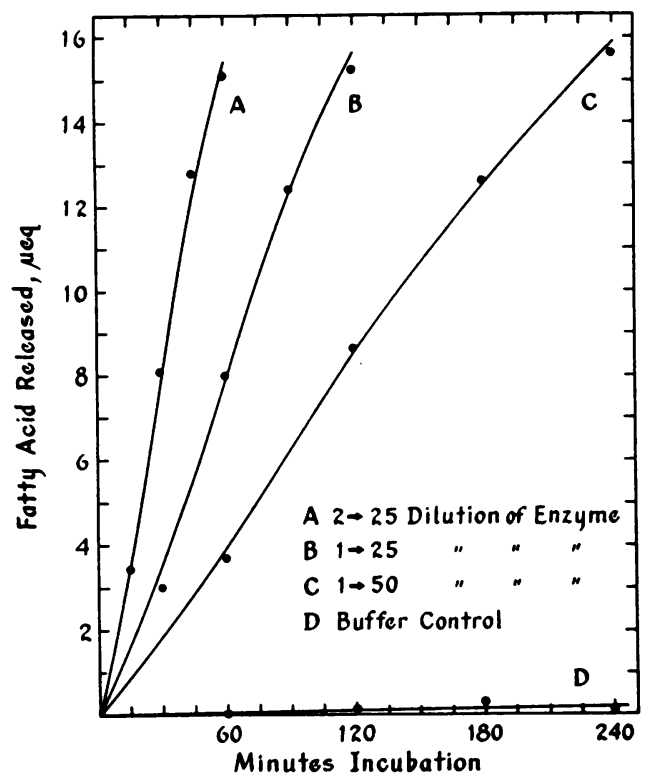

Fig. 7. EFFect of Dilution of ENZYME ON RATE of REACTION. Three separate dilutions of the enzyme were incubated in the final system defined in the text. A control of $1 \mathrm{ml}$ of buffer was included.

TABLE I

The enzymatic conversion of lecithin to lysolecithin*

\begin{tabular}{|c|c|c|c|c|c|}
\hline Sample & Time & $\begin{array}{l}\text { Fatty } \\
\text { acids } \\
\text { released }\end{array}$ & $\begin{array}{l}\text { Lecithin } \\
\text { decrease }\end{array}$ & $\begin{array}{c}\text { Lysolecithin } \\
\text { increase }\end{array}$ & $\begin{array}{c}\text { Lecithin } \\
+ \\
\text { lysolecithin }\end{array}$ \\
\hline & hrs & $\mu E q$ & $\mu$ moles $P$ & umoles $P$ & $\mu$ moles $P$ \\
\hline A & $\begin{array}{r}0 \\
1 \\
2 \\
18\end{array}$ & $\begin{array}{r}5.9 \\
12.0 \\
27.5\end{array}$ & $\begin{array}{r}5.0 \\
11.4 \\
26.5\end{array}$ & $\begin{array}{r}6.0 \\
10.9 \\
27.0\end{array}$ & $\begin{array}{l}29.9 \dagger \\
30.9 \\
29.4 \\
30.3\end{array}$ \\
\hline B & $\begin{array}{r}0 \\
18\end{array}$ & 29.9 & 28.8 & 29.8 & $\begin{array}{l}29.4 \\
30.4\end{array}$ \\
\hline $\mathrm{C}$ & $\begin{array}{r}0 \\
18\end{array}$ & 29.6 & 27.7 & 28.4 & $\begin{array}{l}30.7 \dagger \\
30.4\end{array}$ \\
\hline $\mathrm{D}$ & $\begin{array}{r}0 \\
18\end{array}$ & 29.6 & 31.0 & 29.3 & $\begin{array}{l}32.0 \dagger \\
30.3\end{array}$ \\
\hline $\mathrm{E}$ & $\begin{array}{r}0 \\
18\end{array}$ & 29.4 & 29.8 & 29.5 & $\begin{array}{l}30.9 \dagger \\
30.6\end{array}$ \\
\hline Control & $\begin{array}{r}0 \\
18\end{array}$ & 0.3 & $(+0.3)$ & 1.0 & $\begin{array}{l}29.8 \\
31.1\end{array}$ \\
\hline Control & $\begin{array}{r}0 \\
18\end{array}$ & 0.6 & 1.4 & 0.9 & $\begin{array}{l}30.8 \\
30.3\end{array}$ \\
\hline
\end{tabular}

* Duodenal collections and buffer controls were incubated in the system described. Dilutions were 1:32 for sample $A$ and $1: 10$ for $B$ through $E$.

$\dagger$ Average of duplicate chromatography for lecithin and lysolecithin. at $\mathrm{pH} 8.45$ and room temperature was used to dilute the enzyme and prepare the substrate. The substrate contained $25 \mathrm{mg}(31.1 \mu \mathrm{M})$ lecithin and $20 \mathrm{mg}(48.2 \mu \mathrm{M})$ sodium deoxycholate dissolved in $5.0 \mathrm{ml}$ glycine borate buffer. After $1.0 \mathrm{ml}$ enzyme and an adequate volume of substrate were

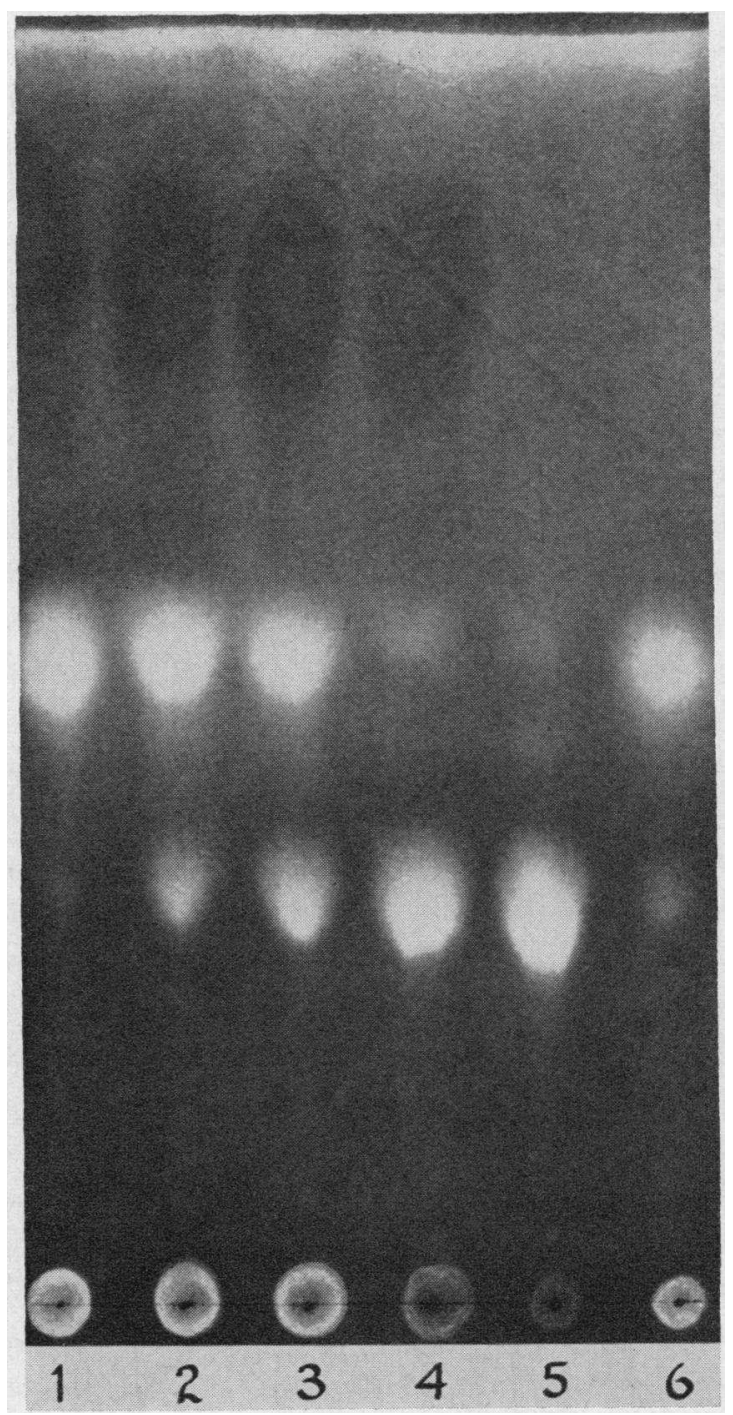

Fig. 8. Chromatogram of the ReAction in the INCUBATION SYSTEM. The conversion of lecithin to lysolecithin in Table $I$, sample $A$, is shown after chromatography and staining with rhodamine $\mathrm{G} ; 100 \mu \mathrm{l}$ aliquots of extracts of the 0 time and 1,2, and 18 hour incubations were applied at origins $1,2,3$, and 4 , respectively. Relatively pure lysolecithin [ $\beta$-monostearoyl)-glycerylphosphorylcholine] and lecithin [(dipalmitoleyl)-glycerylphosphorylcholine] were applied at origins 5 and 6 , respectively. The deoxycholate of the system appeared as the darker areas above lecithin. 
heated separately at $55^{\circ} \mathrm{C}$ for 30 minutes, $5.0 \mathrm{ml}$ of substrate was added to the enzyme for the incubation at $55^{\circ} \mathrm{C}$.

Effect of dilution of the ensyme. As shown in Figure 7 , the rate of the reaction was essentially zero order up to the point of 50 per cent utilization of the lecithin. A slight initial lag in the reaction rate is evident.

Test of the system. Five duodenal collections from different individuals were incubated in the optimal system. The release of fatty acids and the conversion of lecithin to lysolecithin were measured. The data in Table I show that the two methods of measuring activity check closely, and that even at the prolonged period of 18 hours the reaction proceeds only to lysolecithin as evidenced by the recovery of the original lecithin phosphorus. A chromatogram illustrating the reaction in sample A, Table I is shown in Figure 8.

Effect of reaction products. The effect of the reaction products of the system is shown in Figure 9. A slight activating effect of lysolecithin was observed. Oleic acid was used as a representative fatty acid reaction product. It was inhibitory at a concentration which is present when 50 per cent of the lecithin in the system has been hydrolyzed.

Inhibitory factors. Suppression of enzymatic activity by various substances is illustrated in Figure

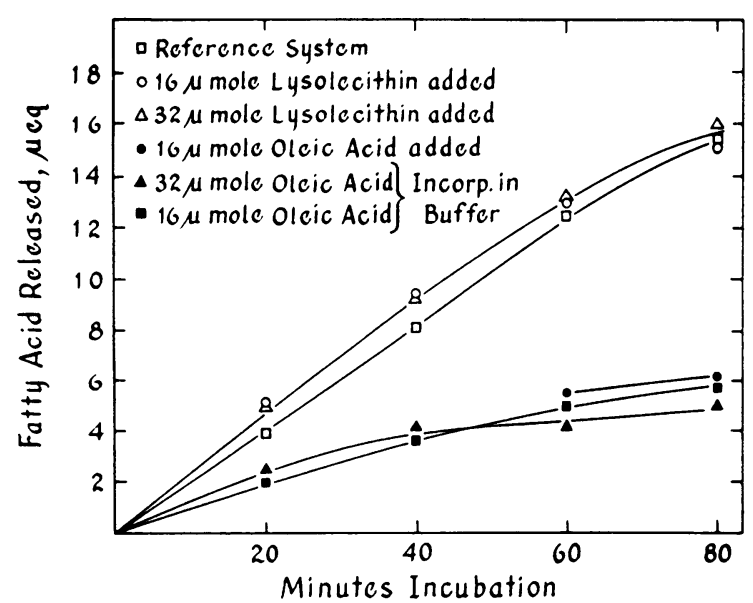

Fig. 9. EFFect of Reaction products in the INCUBATION System. The substrate as defined in the text was modified for three incubations to incorporate 16 or $32 \mu$ moles of lysolecithin or $16 \mu$ moles of oleic acid by addition to the lecithin prior to evaporation of the solvent and incorporation into the substrate. For two incubations oleic acid was added to the glycine and boric acid prior to adjusting to $\mathrm{pH} 8.45$, giving 16 or 32 mmoles of oleic acid in the substrate.

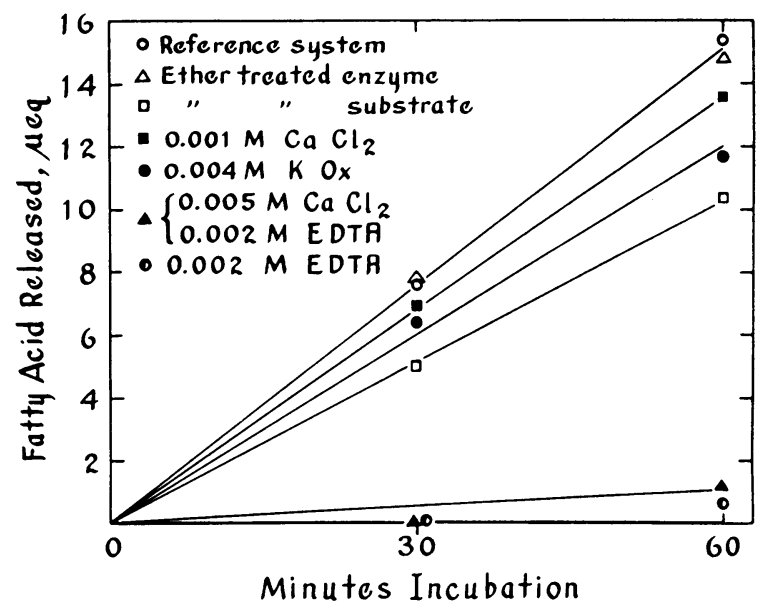

Fig. 10. Inhibition of lecithinase A. Separate standard substrates as defined were modified to include at $\mathrm{pH} 8.45$ a concentration of : 1) $0.001 \mathrm{M}$ calcium chloride, 2) $0.004 \mathrm{M}$ potassium oxalate, 3) $0.002 \mathrm{M}$ EDTA (ethylenediamine tetraacetate), or 4) both $0.005 \mathrm{M}$ calcium and $0.002 \mathrm{M}$ EDT A. In two additional incubations enzyme and substrate were used from which ether had been evaporated prior to pre-incubation heating. In one, $1 \mathrm{ml}$ of Mallinckrodt anhydrous analytical ether was evaporated from each milliliter of enzyme. In the other, $1.67 \mathrm{ml}$ of the same ether was evaporated from each milliliter of substrate.

10. The treatment of enzyme and substrate with diethyl ether was prompted by the observation that inhibition occurred when lecithin was incorporated into the substrate by evaporation of a redistilled peroxide free ether solution of lecithin overlying the buffer. As can be seen in Figure 10, the depressant effect of ether is upon the substrate rather than the enzyme. Both oxalate and calcium have depressant effects. As the concentration of calcium decreased the depressant effect decreased. We have observed the effect of magnesium to be similar to that of calcium. The effect of ethylenediamine tetraacetate was not abolished by first saturating it with calcium, suggesting that its depressant effect was not related to its chelating property. Dialysis of duodenal contents did not reduce activity of the enzyme.

Using the diethyl ether method of Hanahan, without added calcium, the reaction proceeds with $1 \mathrm{ml}$ of undiluted enzyme source to 50 per cent conversion of $31 \mu$ moles of lecithin in 24 hours.

\section{DISCUSSION}

The use of bile salts and amino acids in the system proposed was prompted by their use to en- 
hance lipase activity (16). The formation of choleic acid complexes by deoxycholate (16) and the binding of deoxycholate by calcium must be considered in interpretation of inhibition of the system. Such effects may be due to reducing available deoxycholate below the optimal requirement. Calcium has been shown to be inhibitory for lecithinase A from rat intestinal mucosa (5) but is required for the enzyme in venom (4) and in ox pancreas (6). In our assay system with duodenal drainage, calcium is inhibitory. The concentration of calcium contributed by normal duodenal drainage amounts to $0.00004 \mathrm{M}$, approximately. The quantitative requirement for deoxycholate in the system may be less if it is prepared by means other than precipitation from ether, as it is known that deoxycholate binds ether tenaciously (14). We have also observed that sodium taurocholate and glycocholate, reprecipitated as described, show the same effect on the release of fatty acids as an equimolar amount of deoxycholate.

The enzyme from rat intestinal mucosa is activated by oleic acid, inhibited by cholic acid and is heat labile (5). The marked stability to heat and inhibition by reaction products shown by the enzyme from duodenal drainage is in agreement with studies reported for the enzyme from snake venom, ox pancreas or pancreatin.

The presence and action of the enzyme explains the observation of Borgström (7) that lecithin is converted to lysolecithin in the upper intestine.

\section{SUM MARY}

A lecithinase A was demonstrated in the duodenal contents of man. The release of fatty acids from lecithin was measured titrimetrically. The decrease in lecithin and equivalent increase in lysolecithin were determined independently by quantitative paper chromatography. The action of the enzyme was markedly increased in the presence of sodium deoxycholate and moderately increased by glycine, glutamic acid, arginine or lysine. The optimum medium used for the hydrolysis was a glycine-borate buffer at $\mathrm{pH} 8.5$, and the optimum temperature was $55^{\circ} \mathrm{C}$. Heating in this medium at $80^{\circ} \mathrm{C}$ for 30 minutes did not inactivate the enzyme. The enzyme was partially inhibited by calcium, magnesium, oxalate, oleic acid, and diethyl ether, and nearly completely inhibited by ethylenediamine tetraacetic acid.

\section{ACK NOWLEDGMENT}

We are indebted to Dr. U. S. Seal for helpful criticisms and to Dr. W. J. Henke for the duodenal aspirations.

\section{REFERENCES}

1. Zeller, E. A. Enzymes as essential components of bacterial and animal toxins in The Enzymes, J. B. Sumner and K. Myrback, Eds. New York, Academic Press, 1951, vol. 1, p. 986.

2. Hanahan, D. J. The enzymatic degradation of phosphatidyl choline in diethyl ether. J. biol. Chem. 1952, 195, 199.

3. Hanahan, D. J., Rodbell, M., and Turner, L. D. Enzymatic formation of monopalmitoleyl- and monopalmitoyllecithin (lysolecithins). J. biol. Chem. 1954, 206, 431.

4. Long, C., and Penny, I. F. The structure of the naturally occurring phosphoglycerides. 3. Action of moccasin-venom phospholipase $\mathrm{A}$ on ovolecithin and related substances. Biochem. J. 1957, 65, 382.

5. Epstein, B., and Shapiro, B. Lecithinase and lysolecithinase of intestinal mucosa. Biochem. J. 1959, 71,615 .

6. Rimon, A., and Shapiro, B. Properties and specificity of pancreatic phospholipase A. Biochem. J. 1959, 71, 620 .

7. Borgström, B. Studies of the phospholipids of human bile and small intestinal content. Acta chem. scand. 1957, 11, 749.

8. Marinetti, G. V., and Stotz, E. Chromatography of phosphatides on silicic acid impregnated paper. Biochim. biophys. Acta 1956, 21, 168.

9. Marinetti, G. V., Erbland, J., and Kochen, J. Quantitative chromatography of phosphatides. Fed. Proc. 1957, 16, 837.

10. Lea, C. H., Rhodes, D. N., and Stoll, R. D. Phospholipids. 3. On the chromatographic separation of glycerophospholipids. Biochem. J. 1955, 60, 353.

11. Rhodes, D. N., and Lea, C. H. Phospholipids. IV. On the composition of hen's egg phospholipids. Biochem. J. 1957, 65, 526.

12. Dole, V. P. A relation between non-esterified fatty acids in plasma and the metabolism of glucose. J. clin. Invest. 1956, 35, 150.

13. Beveridge, J. M. R., and Johnson, S. E. The determination of phospholipid phosphorus. Canad. J. Res., E 1949, 27, 159.

14. Sobotka, H. Chemical properties of conjugated and free bile acids in The Chemistry of the Sterids. Baltimore, Williams and Wilkins, 1938, p. 69.

15. Wakui, K., and Kawachi, S. New determination of lecithinase A activity. J. Pharmaceutical Soc. of Japan, 1959, 79, 867.

16. Deuel, H. J., Jr. The Lipids. New York, Interscience Publishers, 1955, vol. 2, pp. 7 and 92. 